\title{
Early post-operative interleukin-6 and tumor necrosis factor- $\alpha$ levels after single-port laparoscopic varicocelectomy in children
}

\author{
Wei Hao $\cdot$ Ivy H. Y. Chan $\cdot$ XueLai Liu \\ Paula M. Y. Tang $\cdot$ Paul K. H. Tam • \\ Kenneth K. Y. Wong
}

Accepted: 3 October 2011 / Published online: 13 October 2011

(C) The Author(s) 2011. This article is published with open access at Springerlink.com

\begin{abstract}
Purpose Laparoendoscopic single-site surgery has recently been described in children and regarded as an improved technology leading to less pain and better cosmetic outcome. Compared to the traditional three-port method, it is not known if the single-port method is less invasive. The aim of this study was thus to investigate the post-operative acute inflammatory response in order to evaluate surgical stress in the two surgical approaches in children.

Methods A prospective, single blinded, case-control study was carried out. Thirteen male patients who presented with unilateral varicocele were divided into two groups. Six children underwent single-port laparoscopic procedure, while the other seven children underwent threeport laparoscopic procedure. Pre-operative and post-operative blood samples were taken for the measurement of tumor necrosis factor- $\alpha$ (TNF- $\alpha$ ) and interleukin 6 (IL-6) using ELISA. Demographics including the operation time, and complications were recorded. Data between the two groups were analyzed using unpaired $t$-test and a $p$ value of $<0.05$ was taken as statistically significant.
\end{abstract}

The authors W. Hao and I.H.Y. Chan are the co-first authors of this article.

W. Hao - I. H. Y. Chan · X. Liu - P. M. Y. Tang

P. K. H. Tam · K. K. Y. Wong ( $\varangle)$

Department of Surgery, The University of Hong Kong, Queen

Mary Hospital, Pokfulam Road, Hong Kong SAR, China

e-mail: kkywong@hku.hk

Present Address:

W. Hao

Department of Pediatrics, Shandong University,

Shandong Provincial Hospital, 44 Wenhua Xi Road,

Jinan 250012, Shandong, People's Republic of China
Results The mean age of patients was 14.5 years (range 12-19 years). There was no significant difference between the two groups in terms of operative time, nor there was any complication recorded. The change in serum TNF- $\alpha$ and IL- 6 concentrations pre- and post-operatively between the single-port group and three-port group was not statistically significant. Overall, patients in the two groups showed excellent satisfaction in terms of post-operative cosmesis.

Conclusion Single-port laparoscopic varicocelectomy is safe, effective and produces excellent cosmesis with minimal surgical stress.

Keywords Single-port laparoscopy · Varicocele . Surgical stress · Interleukin- 6 - Tumor necrosis factor- $\alpha$

\section{Introduction}

Laparoscopic surgery is now a well-accepted alternative and in some cases, is even the preferred treatment modality to open surgery for many conditions. In this regard, the benefits of laparoscopy on postoperative pain, wound cosmesis, hospital stay, and convalescence are widely recognized. Nonetheless, surgeons across the world still strive to improve on existing techniques to try to improve the outcomes of these parameters. Recently, further advances in laparoscopic surgery have resulted in significant innovations, with the emergence of natural orifice transluminal endoscopic surgery (NOTES) and single-port access surgery.

Single-port access surgery, embryonic natural orifice transumbilical endoscopic surgery (E-NOTES) or laparoendoscopic single-site surgery (LESS), which utilizes access via the umbilicus, has received increasing popularity 
recently. With this technique, the surgical scar is virtually concealed within the umbilicus, an embryonic natural orifice [1-3]. Furthermore, there is no concern like those seen in NOTES procedures. The technique was firstly described by Pelosi and Navarra [4, 5] for single-puncture laparoscopic appendectomy and cholecystectomy. Since then, references for LESS have been well reported in adults and children [1, 6-8]. Due to the hidden intra-abdominal entry point in the umbilicus, the feature of "scarless" has made it as a rapidly evolving field.

Despite worldwide enthusiasm, only scarce data are available comparing traditional three-port method with the single-port method in terms of post-operative stress. Although post-operative stress typically encompasses a wide range of endocrinologic, immunologic and hematologic effects, the markers of inflammation are mostly secondary to tissue injury from the minimally invasive procedures. Initial inflammatory response, stimulated by tissue trauma or sepsis, is characterized by the production of pro-inflammatory cytokines, in which interleukin-6 (IL6 ) and tumor necrosis factor alpha (TNF- $\alpha$ ) are regarded as influential and widely investigated in inflammation research [9]. Surgery provokes an early increase in circulating levels of IL-6 within 1-3 h [10]. The level will remain elevated for $2-3$ days postoperatively $[1,7]$. On the other hand, an increase in TNF- $\alpha$ level is seen in patients with post-operative sepsis [11]. Thus, the increase in IL-6 but not TNF- $\alpha$ may reflect post-operative stress due to tissue trauma alone, which in turn, is dependent on operative time, blood loss, and the extent of tissue trauma [6]. We may thus argue that higher levels of IL- 6 form the single-port method is expected since it involves a $2.5 \mathrm{~cm}$ incision versus three $5 \mathrm{~mm}$ incisions totaling only $1.5 \mathrm{~cm}$. The primary aim of this study was to investigate early postoperative stress response in order to evaluate surgical stress in children who underwent single-port and three-port laparoscopic varicocelectomy. Secondary outcomes also included clinical parameters and post-operative wound cosmesis.

\section{Methods}

A single-blinded, prospective case-control study was carried out between September 2009 and March 2010 on 14 boys (mean age $=14.5$ years, range $12-19$ years) who presented with unilateral varicoceles. The children who underwent surgery all had grade III varicoceles. Six children underwent single-port laparoscopic procedures while the other seven children received traditional three-port laparoscopic procedures. All subjects had no sign of inflammatory disease before surgery. Operations were performed under general anesthesia and carried out by two specialist surgeons for this study. Informed consent was obtained from each patient according to the protocol of the Ethics Committee of the Queen Mary Hospital of the University of Hong Kong.

\section{Operative techniques}

For the single-port laparoscopic technique, a $2.5 \mathrm{~cm}$ transumbilical incision was made down to the peritoneal cavity. Under direct vision, Triport ${ }^{\mathrm{TM}}$ (Olympus Inc., USA), a specially designed single port with three inserts, was placed into the peritoneal cavity and secured. A $5 \mathrm{~mm}$ laparoscope was used for visualization and two $5 \mathrm{~mm}$ straight working instruments were inserted. The testicular vessels were clipped en mass and divided. For the traditional three-port method, a $5 \mathrm{~mm}$ camera port was inserted transumbilically. Two further $5 \mathrm{~mm}$ working ports were inserted in the right and left flanks, respectively.

\section{Blood collection and ELISA assay}

Blood samples were taken before surgery and $1 \mathrm{~h}$ after surgery by the same nurse. Blood samples were allowed to clot for $30 \mathrm{~min}$, and then centrifuged for $15 \mathrm{~min}$ at $1000 \times g\left(4^{\circ} \mathrm{C}\right)$. Serum was aliquoted and stored at $-80^{\circ} \mathrm{C}$ until testing. The samples were thawed once and assays were conducted in triplicate. Serum IL- 6 and TNF- $\alpha$ levels $(\mathrm{pg} / \mathrm{ml})$ were determined by quantitative sandwich enzyme immunoassay using Human High Sensitivity ELISA kits (R \& D Systems, Minnesota, USA). The manufacturer's instructions were followed for testing. Reported sensitivity thresholds in plasma to be 0.5 and $0.156 \mathrm{pg} / \mathrm{ml}$ for TNF- $\alpha$ and IL-6, respectively. All laboratory tests were conducted by the same staff who was blinded to the clinical status of the individual subjects.

\section{Clinical variables}

Medical history and demographic data were collected prospectively including operative time, blood loss, postoperative complications, analgesic requirements and hospital stay. Post-operative pain was measured 2 and $4 \mathrm{~h}$ post-operation and just prior to discharge, using the visual analog (VAS) (Fig. 1) [12]. If the score was $\geq 4$, the patients were given paracetamol at $15 \mathrm{mg} / \mathrm{kg} / \mathrm{dose}$.

Patient satisfaction on post-operative scar appearance was surveyed at outpatient visit 3 months after the surgery. Cosmetic result was scored by patients using the following scale: unsatisfactory $=0$, satisfactory $=1$, good $=2$, and excellent $=3$. 


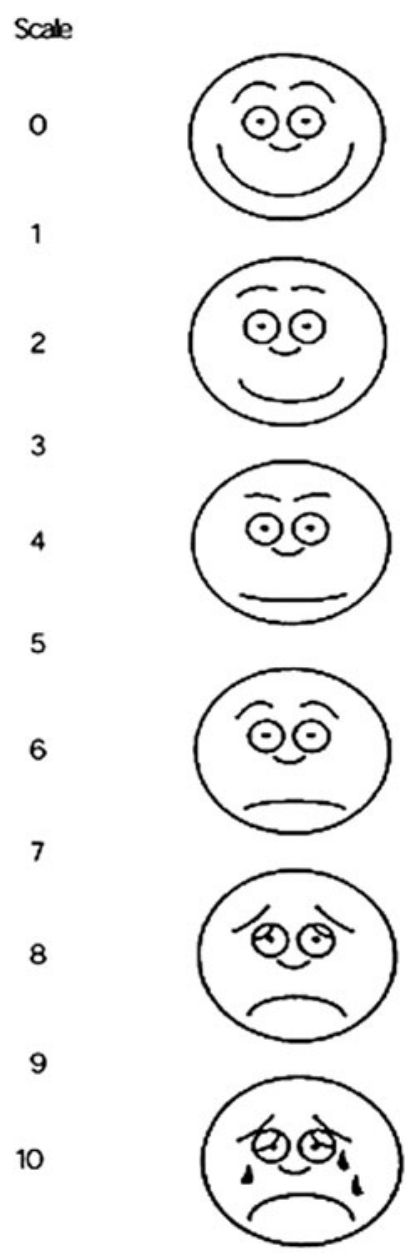

Fig. 1 The use of visual analog scale for assessment of postoperative pain

\section{Statistical analysis}

Unpaired $t$-test with mean and standard deviations was used for comparisons of percentages and means for normally distributed data and a $p$ value of $<0.05$ was considered to be significant.

\section{Results}

The average age in single-port group was $15.3 \pm 2.6$ years and $13.7 \pm 1.6$ years in three-port group. All procedures were completed successfully by using either the single-port or three-port technique. There was no significant difference between the two groups in terms of operative time, postoperative complications recorded, and analgesic usage (Table 1). Every umbilical incision was hidden nicely within the umbilicus. At a mean follow-up of 7.8 (range 6-10) weeks, there was excellent cosmetic result, even with a larger $2.5 \mathrm{~cm}$ incision in the single-port group
Table 1 Demographic, peri-operative and post-operative data of patients

\begin{tabular}{llll}
\hline & $\begin{array}{l}\text { Single-port } \\
\text { group } \\
(n=6)\end{array}$ & $\begin{array}{l}\text { Three-port } \\
\text { group } \\
(n=7)\end{array}$ & $p$ value \\
\hline Age at operation (years) & $15.3 \pm 2.6$ & $13.7 \pm 1.6$ & $>0.05$ \\
$\begin{array}{l}\text { Operative time (minutes) } \\
\text { Blood loss (mls) }\end{array}$ & $38.5 \pm 6.9$ & $33.3 \pm 13$ & $>0.05$ \\
$\begin{array}{l}\text { Doses of paracetamol } \\
\text { required }\end{array}$ & $0.71 \pm 0.18$ & $0.57 \pm 0.2$ & $>0.05$ \\
\begin{tabular}{l} 
Hospital stay (days) \\
\hline
\end{tabular} & $0.33 \pm 0.52$ & $0.43 \pm 0.53$ & $>0.05$ \\
\hline
\end{tabular}

(Fig. 2), with no recurrence or surgical complications as hydrocele, infection, or incisional hernia.

Changes in inflammatory cytokine profiles

The change of TNF- $\alpha$ concentration in serum was $0.324 \pm 0.406 \mathrm{pg} / \mathrm{ml}$ between pre- and post-operatively in the single-port group $(n=6)$, while in the three-port group $(n=7)$, the change of its level was $0.329 \pm 0.952 \mathrm{pg} / \mathrm{ml}$ $(p=\mathrm{ns})$. There was no significant difference in the change between groups (Fig. 3a).

The change of IL-6 in serum concentration was $0.151 \pm 0.392 \mathrm{pg} / \mathrm{ml}$ between pre- and post-operatively in the single-port group, and in the three-port group, the change of its level was $0.097 \pm 0.929 \mathrm{pg} / \mathrm{ml}(p=\mathrm{ns})$. No significant difference could be seen in the change between groups (Fig. 3b).

\section{Cosmesis and patient satisfaction}

Patients' satisfaction on the cosmesis was not significantly different, although there seemed to be a trend towards better satisfaction in the single-port group (Table 2).

At 3 months postoperatively, the mean cosmetic score was 2.71 for the single-port group and 2.57 for the three-port group.

\section{Discussion}

Laparoendoscopic single-site surgery (LESS) marked the beginning of a new era in the field of modern minimally invasive surgery. Refinement and modification of laparoscopic instrumentation has resulted in a substantial increase in the use of LESS over the past 4 years. Several centers have already demonstrated the feasibility and safety of LESS in patients with urologic disorders [13-16]. In LESS pediatric procedures, decreased post-operative pain, improved cosmesis and faster recovery have been reported [8]. Traditional laparoscopic operation requires three to six ports. Each port increases the potential risk of bleeding, 


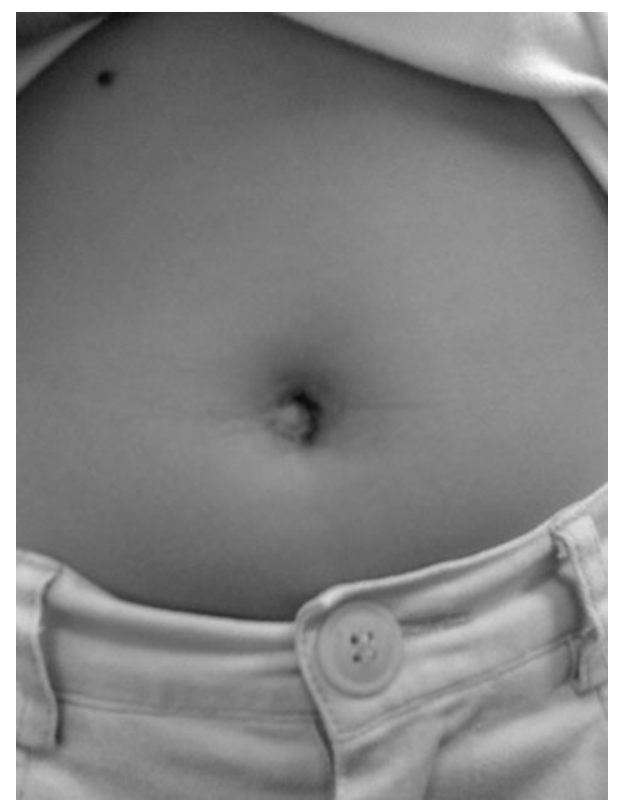

Fig. 2 A post-operative photograph of the umbilical wound taken 1 month after single-port varicocelectomy

port-site hernia, internal organ damage, and decreases cosmetic outcome [17-19]. Single-port laparoscopic surgery could greatly reduce the aforementioned problems of laparoscopic surgery. Indeed, many recent reports in adults have been published to show the advantages of singleport procedures over the traditional three-port approach [1, 14-16, 20-24]. However, compared to the traditional three-port method in children, the exact advantages for single-port method are sparse.

Surgical stress is characterized by an induced production of pro-inflammatory cytokines $[25,26]$, TNF- $\alpha$ and IL- 6 are two well-known pro-inflammatory cytokines which are thought to be central mediators in the cytokine cascades, and also important cytokines for immune and inflammatory response. The changes in serum TNF- $\alpha$ and IL- 6 concentration are sensitive indicators of the post-operative acute phase inflammatory reaction and surgical stress [27-29]. However, only a rise in IL-6, but not TNF- $\alpha$ is seen in stress due to tissue trauma. Thus, in our preliminary study, these two cytokines were used to evaluate and differentiate surgical stress and injury between single-port and three-port laparoscopic varicocelectomy in children. LESS pediatric procedure needs one bigger incision to be passed through by three trocars. A lack of triangulation among right, left instruments and the laparoscope makes procedure more difficult to perform. Furthermore, external instruments may clash inside the peritoneal cavity. In addition, the operation time will be longer for surgeons who lack adequate experience. These negative factors may result in an increase in the level of inflammatory response. In our study, results showed that there were no significant differences between
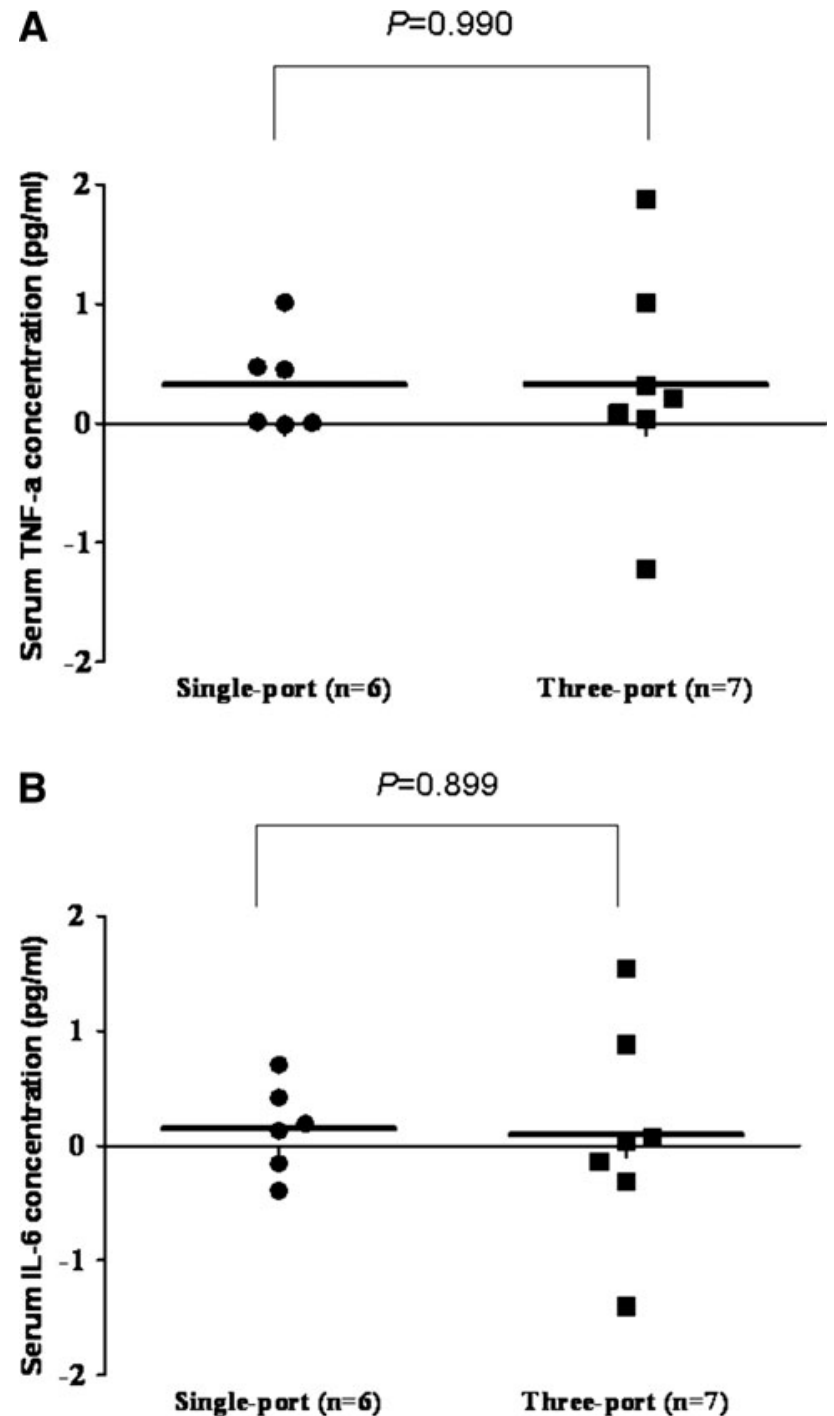

Fig. 3 Dot plot indicates the change of TNF- $\alpha$ (a) and IL-6 (b) concentration in serum between pre- and post-operatively in two groups. The horizontal line in dot clusters of each individual group indicates the mean values in the corresponding groups. Unpaired $t$-test was used for comparison between 2 groups

Table 2 Post-operative cosmetic scores after 3 months

\begin{tabular}{lll}
\hline $\begin{array}{l}\text { Single-port } \\
\text { group } \\
(n=6)\end{array}$ & $\begin{array}{l}\text { Three-port } \\
\text { group } \\
(n=7)\end{array}$ & $p$ value \\
\hline 2.71 & 2.57 & $p>0.05$ \\
\hline
\end{tabular}

the two groups in terms of clinical data. We believe that with the improvement of laparoscopic instruments, and the accumulation of experience, the advantages of LESS surgery in the pediatric population will become more apparent. Nonetheless, there are some important limitations of the current study. First, our findings were limited by the small number of patients included. Second, the disease category 
chosen was relatively minor and thus the overall postoperative inflammatory response would be low, no matter what technique was used. These should be overcome in a future larger study on a different disease condition.

Laparoendoscopic single-site surgery probably represents the next evolutionary step in laparoscopic surgery. However, as we are only at the beginning of a new minimally invasive technology, some questions surrounding the use of LESS still remain unanswered. Firstly, the technical challenges of performing LESS due to minimal or no triangulation of the instruments has to be overcome, and this is limited by the equipment available, as least in the pediatric population. Furthermore, several related clinical questions must be considered. For example, what is the best way to extract large specimens? In addition, patients' attitudes about scar-free surgery have only been evaluated by a simple questionnaire. The differences of cost between single- and three-port laparoscopy are also not known.

In conclusion, we showed in our preliminary study that LESS produced similar stress response to traditional laparoscopy. Further clinical investigations and longer followup period are necessary to elucidate the true benefit and utility of this novel surgical approach compared to current alternatives.

Open Access This article is distributed under the terms of the Creative Commons Attribution Noncommercial License which permits any noncommercial use, distribution, and reproduction in any medium, provided the original author(s) and source are credited.

\section{References}

1. Canes D, Desai MM, Aron M, Haber GP, Goel RK, Stein RJ, Kaouk JH, Gill IS (2008) Transumbilical single-port surgery: evolution and current status. Eur Urol 54:1020-1029

2. de la Fuente SG, Demaria EJ, Reynolds JD, Portenier DD, Pryor $\mathrm{AD}$ (2007) New developments in surgery: natural orifice transluminal endoscopic surgery (NOTES). Arch Surg 142:295-297

3. Kalloo AN, Singh VK, Jagannath SB, Niiyama H, Hill SL, Vaughn CA, Magee CA, Kantsevoy SV (2004) Flexible transgastric peritoneoscopy: a novel approach to diagnostic and therapeutic interventions in the peritoneal cavity. Gastrointest Endosc 60:114-117

4. Pelosi MA, Pelosi MA 3rd (1992) Laparoscopic appendectomy using a single umbilical puncture (minilaparoscopy). J Reprod Med 37:588-594

5. Navarra G, Pozza E, Occhionorelli S, Carcoforo P, Donini I (1997) One-wound laparoscopic cholecystectomy. Br J Surg 84:695

6. Ponsky TA, Diluciano J, Chwals W, Parry R, Boulanger S (2009) Early experience with single-port laparoscopic surgery in children. J Laparoendosc Adv Surg Tech A 19:551-553

7. Gumbs AA, Milone L, Sinha P, Bessler M (2009) Totally transumbilical laparoscopic cholecystectomy. J Gastrointest Surg 13:533-534

8. Kaouk JH, Palmer JS (2008) Single-port laparoscopic surgery: initial experience in children for varicocelectomy. BJU Int 102:97-99
9. Hackam DJ, Rotstein OD (1998) Host response to laparoscopic surgery: mechanisms and clinical correlates. Can J Surg 41:103-111

10. Sweed Y, Puri P, Reen DJ (1992) Early induction of IL-6 in infants undergoing major abdominal surgery. J Pediatr Surg 27(8):1033-1036

11. Kragsbjerg P, Holmberg H, Vikerfors T (1995) Serum concentrations of interleukin-6, tumour necrosis factor-alpha, and C-reactive protein in patients undergoing major operations. Eur J Surg 161(1):17-22

12. Stinson J, Kavanagh T, Yamada J, Gill N, Stevens B (2006) Systematic review of the psychometric properties, interpretability and feasibility of self-report pain intensity measures for use in clinical trials in children and adolescents. Pain 125(1-2): $143-157$

13. Desai MM, Rao PP, Aron M, Pascal-Haber G, Desai MR, Mishra S, Kaouk JH, Gill IS (2008) Scarless single port transumbilical nephrectomy and pyeloplasty: first clinical report. BJU Int 101:83-88

14. Kaouk JH, Goel RK, Haber GP, Crouzet S, Desai MM, Gill IS (2008) Single-port laparoscopic radical prostatectomy. Urology 72:1190-1193

15. Raman JD, Bagrodia A, Cadeddu JA (2009) Single-incision, umbilical laparoscopic versus conventional laparoscopic nephrectomy: a comparison of perioperative outcomes and shortterm measures of convalescence. Eur Urol 55:1198-1204

16. Raman JD, Cadeddu JA (2008) Single access laparoscopic nephrectomy. Indian J Urol 24:457-460

17. Tracy CR, Raman JD, Cadeddu JA, Rane A (2008) Laparoendoscopic single-site surgery in urology: where have we been and where are we heading? Nat Clin Pract Urol 5:561-568

18. Lowry PS, Moon TD, D’Alessandro A, Nakada SY (2003) Symptomatic port-site hernia associated with a non-bladed trocar after laparoscopic live-donor nephrectomy. J Endourol 17: 493-494

19. Marcovici I (2001) Significant abdominal wall hematoma from an umbilical port insertion. JSLS 5:293-295

20. Msezane LP, Mushtaq I, Gundeti MS (2009) An update on experience with the single-instrument port laparoscopic nephrectomy. BJU Int 103:1406-1408

21. Aron M, Canes D, Desai MM, Haber GP, Kaouk JH, Gill IS (2009) Transumbilical single-port laparoscopic partial nephrectomy. BJU Int 103:516-521

22. Barret E, Sanchez-Salas R, Kasraeian A, Benoist N, Ganatra A, Cathelineau X, Rozet F, Galiano M, Vallancien G (2009) A transition to laparoendoscopic single-site surgery (LESS) radical prostatectomy: human cadaver experimental and initial clinical experience. J Endourol 23:135-140

23. White WM, Goel RK, Kaouk JH (2009) Single-port laparoscopic retroperitoneal surgery: initial operative experience and comparative outcomes. Urology 73:1279-1282

24. Lee YS, Kim JH, Moon EJ, Kim JJ, Lee KH, Oh SJ, Park SM, Hong TH (2009) Comparative study on surgical outcomes and operative costs of transumbilical single-port laparoscopic appendectomy versus conventional laparoscopic appendectomy in adult patients. Surg Laparosc Endosc Percutan Tech 19:493-496

25. Davies MG, Hagen PO (1997) Systemic inflammatory response syndrome. Br J Surg 84:920-935

26. Novitsky YW, Litwin DE, Callery MP (2004) The net immunologic advantage of laparoscopic surgery. Surg Endosc 18:1411-1419

27. Zhang RJ, Wild RA, Ojago JM (1993) Effect of tumor necrosis factor-alpha on adhesion of human endometrial stromal cells to peritoneal mesothelial cells: an in vitro system. Fertil Steril 59:1196-1201 
28. Wortel CH, van Deventer SJ, Aarden LA, Lygidakis NJ, Büller HR, Hoek FJ, Horikx J, ten Cate JW (1993) Interleukin-6 mediates host defense responses induced by abdominal surgery. Surgery 114:564-570
29. van Berge Henegouwen MI, van der Poll T, van Deventer SJ, Gouma DJ (1998) Peritoneal cytokine release after elective gastrointestinal surgery and postoperative complications. Am J Surg $175: 311-316$ 